\title{
Buddhist Endowments by Śaiva Kings under the Maitrakas of Valabhī in Western India (5th-8th Cent.) and the Yodhāvaka Grant of Dharasena IV, [Valabhī] Year $3^{26}$
}

\author{
Annette Schmiedchen \\ Humboldt University, Berlin, Germany \\ annette.schmiedchen@hu-berlin.de
}

\begin{abstract}
The phenomenon of interreligious patronage on the Indian subcontinent in the premodern period is best attested in royal inscriptions recording religious endowments. It is striking that most pre-Islamic Indian rulers patronised priests, monks, ascetics, and religious establishments of multiple faiths. The personal religious affiliations of the kings often contrasted remarkably with the patronage patterns followed by them according to the testimony of their epigraphs. The strongest indication for the individual confessions of rulers is given by the religious epithets among their titles. While the ambivalent relationship between the personal beliefs of the kings and their donative practices has been repeatedly described as an expression of Indian religious "tolerance" or of the specific character of Indian religious traditions, this paper emphasises that there were several reasons for the dichotomy. This will be investigated on the basis of the epigraphic material of the Maitraka dynasty, which ruled in Gujarat from the $5^{\text {th }}$ to the 8 th centuries. The article also contains an edition and translation of the hitherto unpublished Yodhāvaka Grant of Dharasena IV.
\end{abstract}

\section{Keywords}

India - Maitraka dynasty - Buddhism - Mahāyāna - Śaivism - royal endowments 


\section{Introduction}

Compared to the early historic period, the so-called early medieval period, especially the time between the 6th and 1oth centuries, was characterised by a remarkable decrease in evidence for private religious donations and grants compared to royal religious endowments in many regions of the Indian subcontinent. ${ }^{1}$ Hence, a specific, almost pan-Indian, type of documentary evidence is the major source for any study of endowments in this period: royal copper-plate charters ${ }^{2}$ in Sanskrit recording pious grants for the regular support of religious persons and institutions.

According to the traditional understanding of a foundation (German: "Stiftung") in medieval Latin Christianity, "a material endowment constitutes a necessary condition by whose regular revenues the goal of the foundation is fulfilled". ${ }^{3}$ In contrast, an initial endowment (German: "Gründungsausstattung") of monasteries and temples with property was apparently not obligatory in medieval India. However, the founder of an institution often seems to have petitioned the king as his overlord for a landed endowment for the permanent maintenance of this institution. ${ }^{4}$ At least this is what the epigraphic evidence tells us.

If we adopt the terminology of Latin Christianity, this means that, in practice, different people were responsible for the fundatio (the foundation) and the dotatio (the endowment). ${ }^{5}$ In the first three centuries CE, it had been not unusual that a lay follower of Buddhism erected a cave monastery at the Indian West coast (= fundatio) and deposited some capital with a guild for the regular support of the monks living in this monastery from the interest of that money (= dotatio $) .6$ But in the early medieval period, private donors seem to have focussed on the foundation of monasteries and temples, whereas kings supported religious persons and institutions through the permanent transfer of the tax revenue from villages. This change in patronage patterns may

1 The present contribution is a result of the project DHARma "The Domestication of 'Hindu' Asceticism and the Religious Making of South and Southeast Asia". This project has received funding from the European Research Council (ERC) under the European Union's Horizon 2020 research and innovation programme (grant agreement no. 809994). An earlier version of this paper was presented at the online conference "Interreligious Founding" organised in Berlin from April 8th to 9th, 2021. I would like to thank Dániel Balogh and Ryosuke Furui for their comments and suggestions on an earlier version of this article.

2 Chitwood et al. 2017: 30-33; Francis 2017.

3 Borgolte 2016: 605.

4 Schmiedchen 2016b: 337; Borgolte 2016: 6o5; Chitwood et al. 2017: 32.

5 Schmiedchen 2016c: 421.

6 Njammasch 1971; Falk 2008; Visvanathan 2018. 
have been related to the increasing size of monastic and temple complexes, which probably could not be maintained from a small investment, but instead required the income of whole villages. The role model for this patronage pattern may have been royal endowments for individual Vedic Brahmins (without a discernible temple connection), a type of grant discussed in Brahmanical literature and well attested since late antiquity, which did not require any "foundation" or intervention by third parties.

It is a matter of fact that the concepts and terminology attested in royal copper-plate charters were strongly influenced by Brahmanical theoretical ideas. In addition, Brahmins often acted as the royal officers who composed such endowment records, including the panegyric parts eulogising the dynasty of the donor king. ${ }^{7}$ On the other hand, we find indications for Buddhist influence on the wording of endowment records as well: "[...] the members of the Buddhist samgha had to struggle to get their grants formulated according to their ideas and in accordance to Buddhist legal terminology. [...] It may be this wish to gain influence on or even control of the chancellery that is reflected in the changing wordings. In the end the Buddhists managed to push the development into the desired direction [...]."8 Some Buddhist canonical texts also attempted to make the founder of a monastery responsible for its future maintenance. ${ }^{9}$

Through the increase of religious endowments by kings in the early medieval period, the ruling dynasties, who not only possessed substantial private property, but also had access to the official possessions of the crown, could directly influence and often even dominate the patronage system. With thousands of royal endowments for the maintenance of religious persons and institutions, it was largely the kings who decided which religious traditions were fostered and kept alive. However, many endowment records prove that other parties also exerted significant influence on these processes. Especially when the tax income of villages was granted by rulers, conflicting interests of local, regional, and sometimes even supra-regional elites had to be balanced. With the foundation of monasteries and temples by members of the court, high-ranking officials, traders, etc., somehow preliminary decisions seem to have been made as to which religious institutions would later be patronised by royal endowments. In the endeavour

7 Schmiedchen 2016d: 500; Chitwood et al. 2017: 30.

8 Hinüber 2013: 376-377. See also Hinüber 2009: 163 .

9 For references to such obligations in Mūlasarvāstivāda texts, see Schopen's (1996: 101) remark: "The donors themselves determine that they should provide the financial resources for the future maintenance of their vihäras." 
to win the loyalty of local religious leaders and, at the same time, to gain the backing of their secular supporters among the local and regional elites, many Indian kings provided regular sources of income in the form of villages and land for numerous monasteries and temples, which had not been erected in their name, but on their territory. There may have been also cases where the overlord did not actually grant a village or land, but the subordinate ruler "requesting" an endowment merely pursued the legitimation of this legal act. In any case, the rulers reacted with their endowments to the specific needs and interests of their wider courtly environment, which was a "multi-religious world".

\section{The Maitraka Evidence}

The corpus of inscriptions of the Maitraka dynasty, which ruled in Gujarat, mainly on the Kathiawar peninsula, from the 5 th to the 8 th centuries, is particularly dense and consists of ca. $110^{10}$ copper-plate charters issued by 16 different rulers in favour of various religious recipients. The epithet parama-māheśvara, "highly devoted to Maheśvara (= god Śiva)", was the geographically and chronologically widest-spread and most-used religious title in royal epigraphs of the Indian subcontinent. ${ }^{11}$ Most of the kings of the Maitraka dynasty were also Śaivas (paramamāheśvara), and only some early members of the royal line deviated from this general scheme: Dhruvasena I was described as an adherent of Viṣnu (paramabhāgavata); and Dharapaț̣a was labelled "a devout worshipper of the sun god" (paramādityabhakta). The Maitraka king Guhasena, who reigned at the beginning of the second half of the 6th century, is called a paramamāheśvara in two of his three known copper-plate charters, and an "excellent [Buddhist] lay follower" (paramopāsaka) in the last of his titledeeds; ${ }^{12}$ all three epigraphs record Buddhist endowments.

10 The number 110 includes all the known records where at least the description of the endowment is preserved.

11 Sanderson 2009; 2015; Schmiedchen 2010/11.

12 Schmiedchen 2010/11: 157-158, 162 . 


\section{Pedigree of the Maitrakas of Valabhì}

1. Bhațakka

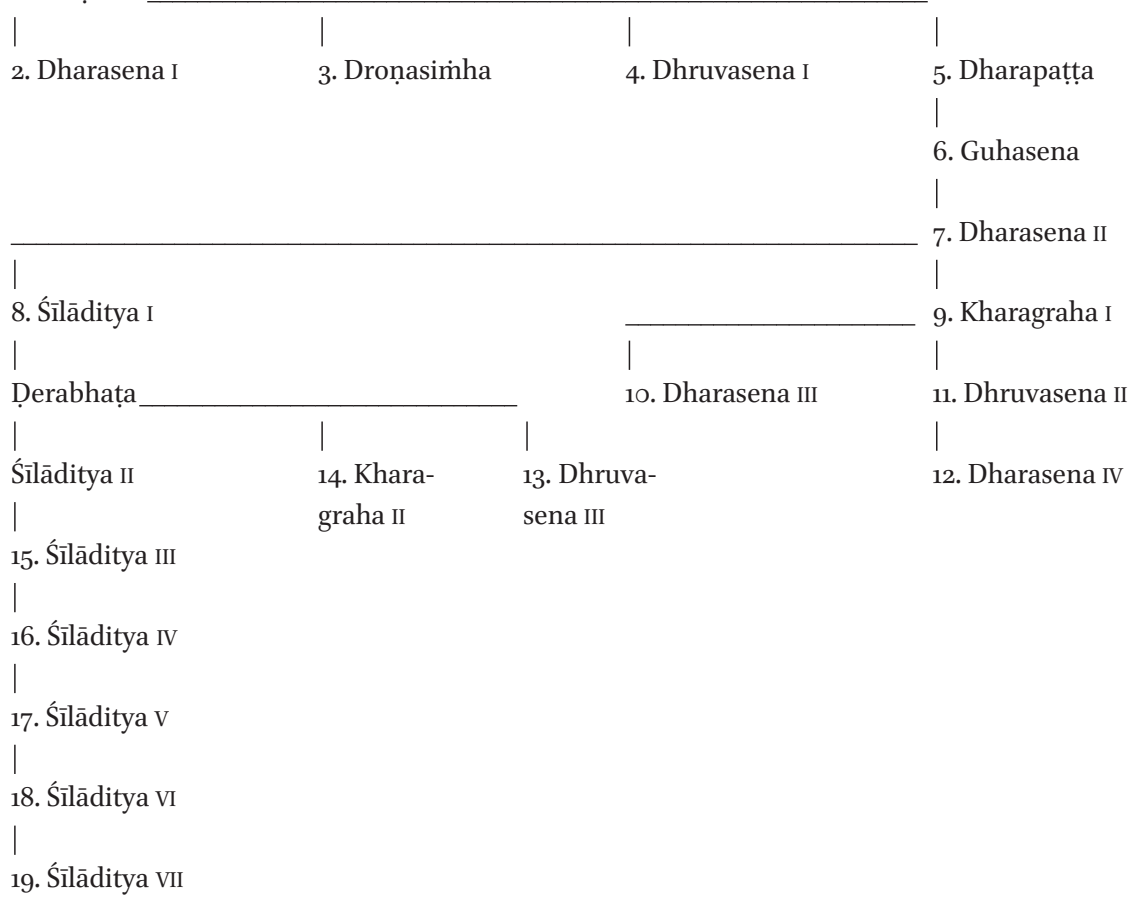

Conforming to a pattern seen widely in the Indian subcontinent, the religious identification of the Maitraka kings did not prevent a wide-spread distribution of their patronage. The vast majority of the charters of the Maitraka dynasty, i.e., seventy per cent, record endowments to Brahmins, to members of the brähmana-varna. One quarter record grants to Buddhist monasteries (vihära), which is a rather large share compared with other regions at that time. Only six epigraphs record donations for "Hindu" deities or temples. ${ }^{13}$ In many parts of the Indian subcontinent, we do see such a picture of religious non-exclusivity.

This paper will mainly focus on the Buddhist endowments of the Maitraka kings. All the copper-plate charters of this dynasty in favour of Buddhist monasteries record grants of villages or, less frequently, of individual plots of land,

13 Five of the six records are published: Bühler 188o; Jackson 1898 (2 grants); Banerji 1931/32; Parikh and Shelat 1988/89. 
i.e., primarily the transfer of the tax income of fields or whole rural settlements to already existing vihäras. Unfortunately, we do not know of separate foundation records for the monasteries in the kingdom. But most of the vihäras mentioned in the inscriptions of this dynasty are characterised as ${ }^{\circ}$ ārita, "erected by [a certain person]". Out of the at least 16 Buddhist institutions referred to in the Maitraka corpus, only a single one definitely had a royal founder: the vihāra established by king Śīāditya I. ${ }^{14}$ Sillāditya I ruled in the early 7 th century and had himself called paramamāheśvara. With this exception, the known Buddhist institutions of the Maitraka kingdom were founded by noble ladies, high-ranking officials, learned monks, and traders or other private individuals.

However, the extant endowment records issued for the upkeep of these vihäras were exclusively made by kings. In contrast to the pattern followed in other regions of India, ${ }^{15}$ the Maitraka charters do not mention petitions by the founders of monastic establishments to the rulers for grants in order to guarantee the maintenance of their foundations. But it can be assumed that the system was perhaps similar. For many of the relevant title-deeds, it cannot be verified when exactly these monasteries, which were sustained by particular royal endowments, had been originally erected. Only if the founders of the institutions were somehow directly connected with the donor kings, can one suppose that not too much time had elapsed. ${ }^{16}$

More than half of the 26 Buddhist Maitraka endowment records were discovered during excavations around Valabhipur (Bhavnagar District), ancient Valabhī, the capital of the dynasty. Buddhist monastic foundations in or near Valabhī are also mentioned in some copper plates whose provenance is unknown. Only two Buddhist charters were discovered in an entirely different region: in Ambalasa in the Talala Taluk of the Junagadh District. ${ }^{17}$ There is no evidence, however, that the Maitraka kings might have funded Buddhist institutions outside Kathiawar.

14 The phrase used is asmatkärita, which means "founded by us". For the text, see Diskalkar 1925: 34, line 22.

15 For Bengal under the Pālas, see Furui 2011: 150-151.

16 See below for such examples.

17 Shastri and Dholakia 1969/70: 235-239; 1970/71: 178-184. 
List of the no extant endowment records of the Maitrakas of Valabhī

\begin{tabular}{|c|c|c|c|c|}
\hline King & Religious epithet & $\begin{array}{l}\text { Buddhist } \\
\text { grants }\end{array}$ & $\begin{array}{l}\text { Brahmanical } \\
\text { grants }\end{array}$ & $\begin{array}{l}\text { Grants to } \\
\text { "Hindu" } \\
\text { deities/ } \\
\text { temples }\end{array}$ \\
\hline Droṇasimha & Paramamāheśvara & - & - & 1 \\
\hline Dhruvasena I & Paramabhāgavata & 4 & 18 & 1 \\
\hline Guhasena & Paramamāheśvara ${ }^{18}$ & 3 & - & - \\
\hline Dharasena II & Paramamāheśvara & 3 & 14 & - \\
\hline Ś̄̄lāditya I & Paramamāheśvara & 7 & 4 & 2 \\
\hline Kharagraha I & Paramamāheśvara & - & 2 & - \\
\hline Dharasena III & Paramamāheśvara & - & 2 & - \\
\hline Dhruvasena II & Paramamāheśvara & 2 & 9 & 2 \\
\hline Dharasena IV & Paramamāheśvara & 3 & 3 & - \\
\hline Dhruvasena III & Paramamāheśvara & 1 & 2 & - \\
\hline Kharagraha II & Paramamāheśvara & - & 1 & - \\
\hline Śīlāditya III & Paramamāheśvara & 3 & 10 & - \\
\hline Śīlāditya IV & Paramamāheśvara & - & 6 & - \\
\hline Śīlāditya v & Paramamāheśvara & - & 4 & - \\
\hline Śīlāditya VI & Paramamāheśvara & - & 2 & - \\
\hline Śīlāditya VII & Paramamāheśvara & - & 1 & - \\
\hline Total & & 26 & 78 & 6 \\
\hline
\end{tabular}

The most famous Buddhist vihära in Valabhī seems to have been the Dudụāvihāra, a monastery (for monks) ${ }^{19}$ founded by and named after princess Duḍ̣ā, a Buddhist laywoman and niece of the Maitraka king Dhruvasena I, an adherent of Viṣnu, who ruled in the second quarter of the 6th century. ${ }^{20}$ The first known endowment of a village for the Duḍạvihāra is attested in a charter of king Dhruvasena I, Ḍuḍāà's uncle, dated $534 \mathrm{CE} .{ }^{21}$ In this copper-plate record, the king is called paramabhāgavata, whereas princess Duḍ̣ā is

\footnotetext{
18 Guhasena was called paramopāsaka in the last of his grants; cf. Bühler 1876b: 207, line 2. His father Dharapațța was a paramādityabhakta; see, e.g., Bühler 1877: 11, line 9.

19 This amendment is made to underline the fact that there were also nunneries in the Maitraka kingdom; see below.

20 Duḍ̣ā was his niece, the daughter of his sister (svabhāgineȳ ), not his sister-in-law, as claimed by Dikshit (1940: 816).

21 Bühler 1875a: 105, line 21.
} 
portrayed as paramopāsikā, "excellent [Buddhist] laywoman", very much in the same way as king Guhasena, probably a nephew of Dhruvasena I, was labelled a paramopāsaka in $567 \mathrm{CE} .^{22}$ The terms upāsaka (m.) and upāsikā (f.) are used in Buddhist texts to denote a special group of lay adherents, ${ }^{23}$ who followed five of the altogether ten prescripts compulsory for monks; paramopāsaka is a religious title attested for kings, but it was not the only title used to express the Buddhist leanings of Indian rulers. ${ }^{24}$

The Maitraka king Guhasena, the nephew of Dhruvasena I, continued to patronise the monastery founded by the niece of Dhruvasena I some decades before: In $566 \mathrm{CE}$, he granted four villages (with one charter) to the Dudụāāmahāvihāra. ${ }^{25}$ King Śīāditya I, a grandson of Guhasena, endowed the Dudụāvihāra with one village, three fields, two irrigation cisterns, and four wells with flower gardens, the last four being situated on the city territory of Valabhī, in $6{ }^{\circ} \mathrm{CE}^{.6}{ }^{26}$ Despite the evidence of this and at least six more Buddhist endowments, despite the fact that he apparently founded a Buddhist vihära, and despite claims made in Buddhist texts that he was a follower of Buddhism, ${ }^{27}$ Ślāditya I seems to have been a Śaiva. At the beginning of his rule, in the early 7 th century, the official account of the dynastic genealogy was rewritten. ${ }^{28}$ One of the major changes was that Silāditya I, himself labelled a paramamāheśvara, had only those of his predecessors mentioned who had been Śaivas as well. Thus, he (or rather his chief secretary) left out even Śilāditya I's own great-grandfather Dharapațta, a paramādityabhakta, "devout worshipper of the sun god". This "Śaiva only" policy seems to have been part of an attempt to homogenise the dynastic tradition. From that time onwards, all the Maitraka kings declared themselves (or were declared) paramamāheśvara. However, still through the middle and second half of the 7 th century, the

22 Bühler 1876b: 207, line 2.

23 Schopen (1994: 43, n. 30): “[...] they appear to have had a particularly close and formally acknowledged relationship with their monastic communities".

24 Other epithets for Buddhist rulers were paramasaugata and paramatāthāgata; see, e.g., Sanderson 2009: 80 - 81; 2015: 201; Schmiedchen 2010/11: 157-163.

25 Bühler 1875b: 174-176.

26 Kielhorn 1885: 327-330.

27 For the report of Xuanzang on "Sīlāditya of Mālava", see Great Tang Dynasty Record 298, 302 (online version); 338, 342 (printed version). For the evidence from the Mañjuśríyamūlakalpa, see Sanderson 2009: 72-73; 2015: 202, n. 103 .

28 Such an account was contained in each copper-plate charter of the Maitrakas. For the new template used, see Schmiedchen 2018a: 39-40. 
successors of Śīāditya I, all Śaiva kings, endowed the Ḍuḍdāvihāra and other Buddhist monasteries with villages.

The Duḍ̣āvihāra, referred to in twelve Maitraka copper-plate records, was called mahāvihāra, "great monastery", in one of these charters, and vihäramandala, "monastic complex", in two of the others. ${ }^{29}$ At least six economically independent structures seem to have been attached to the Duḍ̣āvihāra in the 6 th $/ 7^{\text {th }}$ centuries. This development started already rather early: an inscription of king Dhruvasena I, dated $536 \mathrm{CE}$, mentions a vihära founded by the monk Buddhadāsa as apparently belonging to the Duḍ̣̂avihāra and receiving an endowment of a village from the Maitraka king. ${ }^{30}$ Monasteries established by the monks Vimalagupta and Sthiramati, by the trader Kakkamākila, and by one Gohaka, as well as a Tārā temple erected by the chief secretary (divirapati) Śrī-Skandabhața followed. ${ }^{31}$ There have been attempts to identify some of the learned monks, Sthiramati in particular, also Buddhadāsa, referred to as founders of vihāras in the Maitraka charters with famous Buddhist scholars known from other sources. But these identifications are rather doubtful, as there have been surely multiple Sthiramatis; ${ }^{32}$ and scepticism is probably also justified for a figure like Buddhadāsa. ${ }^{33}$

The Divirapati Śri-Skandabhața, on the other hand, can be relatively clearly identified. Two high-ranking officials of this name, grandfather and grandson, occur in Maitraka inscriptions, no. 1 in the second half of the 6th century, and no. 2 in the second quarter of the 7 th century; "our" Skandabhata was probably the second. Both were chief secretaries of the kings and responsible for the composition of their charters, as is mentioned in these records. The use of the title divirapati is attested for Skandabhata I only at the end of his career, whereas Skandabhața II was called divirapati from the beginning of his career. Skandabhața I worked for the kings Guhasena and Dharasena II; he also composed the charter where Guhasena was called paramopāsaka. ${ }^{34}$ Vatrabhații, probably Skandabhața I's son, took over in the early 7 th century, rewrote the genealogy of Sīlāditya I, describing the dynasty as "Śaiva only", and worked also for Sillāditya's successors. During the second quarter of the 7th

29 Bühler 1875b: 175, line 8; 1877: 15, line 35; Diskalkar 1925: 39, line 21.

30 Bloch 1895: 383 , lines 14-18.

31 For a rough overview, see Shastri 2000: 442.

$3^{2}$ Bühler (1877: 10) was the first to identify this Sthiramati with the "famous pupil of Vasubandhu". Silk (2009: 384-385), however, rightly remarked that "there might have been more than one Sthiramati". See also Kramer 2019.

33 Tournier 2020: 888.

34 Bühler 1876b: 207, line 15. For the activity of Skandabhața I, see also Hinüber 2013: 372. 
century, Skandabhața II, the son of Vatrabhatți, followed in his father's footsteps; Skandabhața II acted as divirapati under the Maitrakas Dhruvasena II and Dharasena IV. Anahila, the son of Skandabhața II, succeeded his father in the third quarter of the 7 th century. But in the late 7 th century, the family tradition in the divirapati office, which had lasted some one hundred years, apparently ended. It is remarkable, however, that up to this point, the same chief secretaries had been taken over even when a king had not been succeeded by his eldest son, but by a member of a collateral branch. Thus, the continuity in the divirapati family seems to have been even stronger than that in the royal line. ${ }^{35}$ It can also be assumed that the chief secretaries were quite influential at the Maitraka court.

This must have had implications for the patronage patterns as well. Skandabhața II apparently founded several Buddhist, notably Mahāyāna, institutions in the Maitraka kingdom. He established a Mahāyānikavihāra in a village named Yodhāvaka in the Hastavapra district in Surāșțra (which is the ancient name for Kathiawar or at least parts of the peninsula). This vihära is the only monastery in the Maitraka kingdom known so far which was explicitly labelled Mahāyāna/Mahāyānika. Divirapati Skandabhața II was also responsible for the composition of the charter dated $644 \mathrm{CE}$, where Dharasena IV, a Śaiva, endowed this Mahāyānikavihāra with the very same village of Yodhāvaka. ${ }^{36}$ Two other charters of king Dharasena IV record endowments of this very same Maitraka king in favour of a temple of the female Bodhisattva named Tārā (Tārāpura, also called devakula or gandhakuțī), erected by the chief secretary Skandabhața II in the village of Kānasīhānaka in Surāșțra. ${ }^{37}$ Mahāyāna textual influence can be already found in three charters composed by Skandabhața I, who was probably the grandfather of Skandabhața II. ${ }^{38}$

Although the majority of vihäras in Valabhī (and in the Maitraka kingdom) were monasteries for monks, it is quite remarkable that there are several references to apparently economically independent nunneries (also called vihāra) in the capital. Four charters found together during excavations near a tank at Vala/Valabhipur in 1930 record endowments in favour of those convents. ${ }^{39}$ Three of the inscriptions refer to a monastic complex for nuns on the city territory of Valabhī, the Yakșaśūravihāra[maṇdala]. Nothing is known about

35 Schmiedchen 2018a: 37-38. See also Hinüber 2013: 373 .

36 Bhandarkar 1872: 45-46. For the edition and translation of this endowment record, see the appendix.

37 Srinivasan 1969/70: 219-224.

38 Schmiedchen 2019: 206.

39 Gadre 1934: 74-85, 88-91. 
Yakșaśüra, except for his name. It is only once explicitly said that he was the founder of the monastery named after him. Besides the vihära probably established by Yakșaśūra, a second monastery for nuns, founded by Pūrṇabhaț̣ā, the mother of a subordinate ruler (sāmanta) named Kakkuka, was attached to this vihäramandala. The nunneries received, like their "male counterparts", whole villages from Śaiva kings of the Maitraka dynasty in the 7th century i.e., from Sīlāditya I and Dhruvasena II.

The standard formula to describe the purpose of Buddhist grants in early medieval India, which was also used in the Maitraka records, was threefold: [1] for the maintenance of the local monastic order; [2] for the worship of the Buddha(s); [3] for the upkeep and repairs of the monastic buildings. ${ }^{40}$ The relevant passage of a Maitraka charter of 6o9 CE reads: "for the use of robes, alms-food, beds and seats, medicine to cure the sick of the noble order of monks coming from the four directions and residing there, for the uninterruptedness regarding fragrance, flowers, garlands, lamps, oil, etc. for the cult and ceremonial bathing of the eminent Buddha(s), and for the purpose of repairing [those parts] of the monastery [which are] split and cracked" (tan-nivāsi-catur-ddig-abhyāgatāryya-bhikșu-sañghasya ca cīvara-pindapāta-śayanāsana-glāna-pratyaya-bhaișajya-parișkāropayogāya bhagavatām ca buddhānāim püjā-snapana-gandha-pușpa-mālya-dīpa-tailädy-aryavacchittaye vihārasya ca khaṇda-sphuțita-pratisamiskārāya). ${ }^{41}$

According to the evidence from the Buddhist endowment records of the 6th/7th-century Maitraka kings, Valabhī, the capital of this dynasty, must have been dotted with monasteries and nunneries, which were mostly non-royal foundations. Unfortunately, no remains of the Valabhī vihäras have been excavated so far. However, the report of the Chinese pilgrim Xuanzang, who travelled through this region in the mid-7th century, corroborates the information on the existence of numerous residential structures for monks in and around Valabhī, stating that there were some one hundred monasteries with some 6, ooo monks in the region of "Falapi" ${ }^{2}$

As has been shown, the epigraphic material attests that Buddhist monks founded monasteries in the city of Valabhī. Royal ladies, high-ranking officials, traders, etc., who were rarely labelled Buddhist lay followers, are said to have

40 Schmiedchen 1993. See also the edition and translation in the appendix.

41 For the Sanskrit text, see Shastri and Dholakia 1970/71: 183, lines 26-29, with modifications. The translation is mine.

42 Great Tang Dynasty Record 301-302 (online version); 342 (printed version). Xuanzang lists the numbers of monasteries and monks of the regions where he travelled to. However, he does not mention any nunneries. 
erected monasteries as well as nunneries in the Maitraka capital. Most of these founders of vihäras might have been permanently based at Valabhī, unlike the Maitraka kings, who must have been frequently absent for military campaigns, as many of their title deeds were issued from so-called "victory camps" (vijayaskandhā $\bar{a} r a$ ), especially from the 7 th century onwards. ${ }^{43}$ However, in the 6 th/7th centuries, the Valabhi monasteries received a number of villages as regular sources of income from the Maitraka kings, which had strong personal leanings towards Śaivism. This patronage pattern is all the more interesting, as the rulers of Valabhī did not merely officially support Buddhism as such, but they extended their patronage, among others, to specific Buddhist groups, which could be regarded as "minorities" - i.e., to nuns (on the city territory of Valabhī) and to Mahāyānins (outside the city limits). ${ }^{44}$

The last extant Buddhist grants of the Maitraka kings date from around $675 \mathrm{CE}$, while donations to Brahmins continued to be made until the end of Maitraka rule (that is, until $765 / 766 \mathrm{CE}$ ). ${ }^{45}$ There is some evidence that internal reasons may have contributed to a decrease in royal patronage of Buddhism. This can be deduced from a comparison of the stipulations in the Buddhist and Brahmanical endowments of the Maitrakas. It is stated that the endowments ought to be utilized "according to the proper condition of a religious grant". A complete clause of this kind in a Brahmanical endowment record might read, e.g.: "Therefore not even a slight hindrance should be made or [any] objection [be raised] by anyone against the one (i.e., the Brahmanical donee) who is, according to the proper condition of a gift in favour of a Brahmin, enjoying [the land/village], cultivating [it], having [it] cultivated, or assigning [it to others for cultivation]" (yato 'syocitayā brahmadāyasthityā bhu[i்]jatah krșatah karșayatah pradiśato vā na kaiścit svalpāpy ābādhā vicāraṇa vā kāryāa $){ }^{46}$ This regulation entitled the recipient to simple usufruct as well as to - at least de iure - more complex usages of the object donated. In particular, when plots of arable land were singled out and then bestowed, the stipulation can be seen

43 Some of the military camps lay just outside the city gates of Valabhī (valabhïpradvāra), whereas others were situated at more distant places, such as present-day Kheda, Bharuch, and Vadnagar in Gujarat, or Ujjain in Madhya Pradesh.

44 See above. For the Mahāyānikavihāra, see the edition and translation of the relevant charter in the appendix.

45 For the last dated Maitraka endowment to a Buddhist monastery, see Diskalkar 1925: 57-63. For the last dated copper-plate charter of the Maitrakas, a Brahmanical grant, see Fleet 1888: 171-191.

46 See, e.g., Sukthankar 1919/20: 257, lines 19-20. 
as even more important, because it permitted the beneficiaries to carry out different degrees of agricultural activity.

A similarly complex equivalent was also used in some Buddhist grants of the Maitrakas. ${ }^{47}$ But often the formula was altered - perhaps after a request by monastic clergy for a more appropriate Buddhist adaptation. Such a modified phrase reads, for example: "Therefore, no impairment should be made or [any] objection [be raised] by anyone against those appointed there, who are having what grows there collected" (yatah tatrādhikrtānām yat tatrotpadyate tad udgrāhayatāìn na kenacit pratiședho vicāranā vā kāryā $).{ }^{48}$ Under king Śīāditya I, a particular formula, stressing the rather passive approach of Buddhist beneficiaries, was used: "Therefore, [the endowment,] being enjoyed according to the proper condition of a rent-free holding in favour of a deity, shall not be obstructed by anyone" (yata ucitayā ca devāgrāhārasthityā bhujyamānakah na kaiścit paripanthaniyah) ${ }^{49}$ In comparison to Brahmanical endowments, this somewhat ambiguous handling of the prescriptions in Maitraka grants to vihäras may be explained by the Buddhists' generally strict attitude towards agriculture and their lack of interest in getting involved in farming. ${ }^{50}$

In many parts of India, a certain decline in Buddhist donations by royal figures can be observed during the early medieval period. Inversely, Brahmins (and later, increasingly, "Hindu" temples) were favoured on an even larger scale. As mentioned, one reason for this development might have been the comparative lack of interest which the Buddhist monasteries showed in the village life; their traditional base in India was in towns and cities rather than the countryside. Brahmins, by contrast, seem to have fulfilled the expectations of the kings, who had their own "agenda" for the official patronage; and Brahmins apparently shaped the rural landscape in a much better way - quite

47 Bühler 1875b: 175, lines 12-13. See also the edition and translation in the appendix.

48 Bühler 1875a: 105, lines 23-25.

49 See, e.g., Kielhorn 1885: 330, line 29. The term devāgrāhāra seems to have denoted grants for collective bodies. See also the edition and translation in the appendix. For agrahāra/agrāhāra, see Sircar 1966: 10-11.

50 Schmiedchen 2019: 208-209. The Chinese Buddhist pilgrim Yijing quoted the comment of a Vietnamese monk on the practice followed in Tämralipti in the 7 th century (Record of the Buddhist Religion 62): "The priests in this monastery are mostly observers of the precepts. As cultivation by the priests themselves is prohibited by the great Sage, they suffer their taxable lands to be cultivated by others freely, and partake of only a portion of the products. Thus they live their just life, avoiding worldly affairs, and free from the faults of destroying lives by ploughing and watering fields." 
a number of them were personally active in agriculture, particularly those that received small plots of land, not whole villages.

\section{Conclusion}

The kings of the Maitraka dynasty, like many Indian rulers, not only supported the religious groups or deities they personally followed. One conventional explanation for the fact that many pre-Islamic Indian rulers patronised different religious groups, i.e., made endowments in favour of the Buddhist, "Hindu"Brahmanical, and Jaina traditions, has been Indian religious tolerance and/or the "specific character of Indian religious traditions", i.e., that the differences between these religions were not as strict as between different belief systems in other parts of the world. In his critique on the assumption of the existence of a "single Hindu religion" since the early medieval period, if not even earlier, Alexis Sanderson has noted: "It is widely believed that this complex unity displays an exemplary degree of religious tolerance, not only between Vaidikas, Vaiṣnavas, Śaivas, Śăktas, Sauras, but also between these and the followers of the other two major faiths of the age, namely Buddhism and Jainism." ${ }^{.51}$ There have been tendencies in the "Hindu" traditions to somehow incorporate the Buddhist (and also the Jaina) faiths, for instance, through declaring the Buddha as one of the avatāras of the god Vișnu. ${ }^{52}$ But in Buddhist and Jaina normative texts, we do find a strong emphasis on their specific identity and distinctiveness. ${ }^{53}$ The Sanskrit endowment records also have preserved these traces of distinctions between different religious groups. ${ }^{54}$ Besides, Indian rulers would have chosen their religious epithets not just "out of the blue", even if one has to admit that the predominant preference for being labelled as paramamāheśvara ("highly devoted to Śiva" or even "paramount Śaiva") may have been related to a certain "mainstream" agenda, using this epithet similarly to the

$51 \quad$ Sanderson 2015: 155; see also Verardi 2011: 41-58.

52 Cf., e.g., Gonda 1954: 159, 162; Matchett 2003: 139; Doniger 20o9: 481-485. See recently also Salomon 2018: 12-13.

53 Sanskrit sources did not only differentiate Buddhism and Jainism from "Hindu" systems, but also the Vaidika (Vedic-Brahmanical), Vaiṣnava, Śaiva, Śākta (goddess-worship), and Saura (sun-worship) traditions; cf. Sanderson 2015: 156.

54 Lévi 1937; Schmiedchen 1993; 2010/11; Sanderson 2009; Hinüber 2009; 2013; Chitwood et al. 2017: 29-36. 
imperial titles parameśvara ("paramount sovereign") and paramabhatțāraka ("supreme ruler").55

Despite this distinctiveness, there was a kind of glue for the Buddhist, "Hindu"-Brahmanical, and Jaina endowment cultures. This was the overarching concept of punya, religious merit, to be obtained, inter alia, through religious gifts and donations, grants and endowments. ${ }^{56}$ In this context, it is worth mentioning that the formula used to describe the religious merit (punya) acquired by royal grants was, despite minor modifications, a pan-religious one in the great majority of official charters, regardless of who the donees were. Mostly, royal endowments (as well as many private gifts) were made "for the increase of the religious merit" of the donor and his parents (e.g., mātāpitror àtmanaś ca punyābhivrddhaye; mātāpitroh punyāpyāyanāya). This was a kind of basic formula, which could be modified and extended. Notwithstanding the differences, the common, trans-religious goal of all those donations was to gain punya. The extant epigraphs are ample evidence that there was a kind of consensus among the followers of the various beliefs regarding the religious merit of pious grants. Future kings were requested to preserve existing donations and were promised a share of punya. ${ }^{57}$ This consensus must have been a major precondition for the coexistence of different endowment cultures on a royal level. However, this patronage system only worked as long as there existed a consensus regarding the punya concept. With the advent of Islam, this consensus ceased to exist.

\section{Bibliography}

\section{Primary Sources}

ARIE 1963/64 = Annual Report of Indian Epigraphy for 1963/64. ARIE 1964/65 = Annual Report of Indian Epigraphy for 1964/65.

Great Tang Dynasty Record = The Great Tang Dynasty Record of the Western Regions

(Taishō, vol. 51, no. 2087), translated by Li Rongxi. Berkeley, CA, 1996 (online version and printed version).

Record of the Buddhist Religion $=A$ Record of the Buddhist Religion as Practised in India and the Malay Archipelago (A.D. 671-695), translated by Junjiro Takakusu. Oxford 1896.

55 For these titles, see Schmiedchen 2018a; 2018b. See also the edition and translation in the appendix.

56 Lévi 1937: 224; Schmiedchen 2016a: 74-79; Einicke 2017: 237-241.

57 See also the edition and translation in the appendix. 


\section{Secondary Literature}

Altekar 1931/32 = A.S. Altekar. "Surat Plates of Karkkaraja Suvarnavarsha of the Gujarat Rashtrakuta Branch: Dated Saka Year 743." Epigraphia Indica 21: 133-147.

Altekar 1934 = A.S. Altekar. The Rāshțrakūțas and Their Times. Pune.

Balogh and Griffiths 2019 = Dániel Balogh and Arlo Griffiths. "Transliteration Guide for Members of the DHARMA Project." https://halshs.archives-ouvertes.fr/ halshs-02272407.

Banerji 1931/32 = R.D. Banerji. "The Bhadreniyaka Grant of Siladitya I; G.E. 292." Epigraphia Indica 21: 116-119.

Bhandarkar 1872 = Ramakrishna Gopal Bhandarkar. "On Two Copperplates from Valabhī." Indian Antiquary 1: 45-46.

Bhandarkar 1927/28-1935/36 = Devadatta Ramakrishna Bhandarkar. "A List of the Inscriptions of Northern India in Brahmi and Its Derivative Scripts, from about 200 A.C." Appendix to Epigraphia India 19-23: 1-406.

Bloch $1895=$ Theodor Bloch. "An Unpublished Valabhī Copper-Plate Inscription of King Dhruvasena I." Journal of the Royal Asiatic Society, New Series, 27: 379-384.

Borgolte 2016 = Michael Borgolte. "Intercultural Perspectives: Foundation Endowments and Revenues." Ed. Michael Borgolte. Enzyklopädie des Stiftungswesens in mittelalterlichen Gesellschaften. Vol. 2: Das soziale System Stiftung. Berlin: 605-611.

Bühler $1875 \mathrm{a}$ = Georg Bühler. "A Grant of King Dhruvasena I. of Valabhī." Indian Antiquary 4: 104-107.

Bühler 1875b = Georg Bühler. "A Grant of King Guhasena of Valabhī." Indian Antiquary 4: $174-176$.

Bühler 1876a = Georg Bühler. "Inscriptions from Kāvī: II. - The Grant of Govindarāja." Indian Antiquary 5: 144-152.

Bühler 1876b = Georg Bühler. "Grants from Valabhī." Indian Antiquary 5: 204-212.

Bühler 1877 = Georg Bühler. "Further Valabhī Grants." Indian Antiquary 6: 9-21.

Bühler 1880 = Georg Bühler. "Valabhī Grants: No. Xv." Indian Antiquary 9: 237-239.

Chitwood et al. 2017 = Zachary Chitwood et al. "Endowment Studies - Interdisciplinary Perspectives." Endowment Studies 1.1:1-59.

Dikshit 1940 = M.G. Dikshit. "A New Vihāra at Valabhī." The Indian Historical Quarterly 16: $816-818$.

Diskalkar 1925 = D.B. Diskalkar. "Some Unpublished Copper-Plates of the Rulers of Valabhī." Journal of the Bombay Branch of the Royal Asiatic Society, New Series, 1: 16-63.

Doniger 2009 = Wendy Doniger. The Hindus: An Alternative History. New York.

Einicke 2009 = Katrin Einicke. Korrektur, Differenzierung und Abkürzung in indischen Inschriften und Handschriften. Wiesbaden. 
Einicke 2017 = Katrin Einicke. "Giving Gifts in Pre-Modern India: The Motivation of the Donors." Ed. Barbara Schuler. Historicising Emotions: Practices and Objects in India, China, and Japan. Leiden: 193-258.

Falk 2008 = Harry Falk. "Money Can Buy Me Heaven. Religious Donations in Late and Post-Kushan India." Archäologische Mitteilungen aus Iran und Turfan 40: 137-148.

Fleet 1888 = John Faitfull Fleet. "Alina Copper-Plate Inscription of Siladitya VII: The Year 447." Inscriptions of the Early Gupta Kings and Their Successors (Corpus Inscriptionum Indicarum, vol. 3). Calcutta: 171-191.

Francis 2017 = Emmanuel Francis. "Indian Copper-Plate Grants: Inscriptions or Documents?" Ed. Alessandro Bausi et al. Manuscripts and Archives: Comparative Views on Record-Keeping. Berlin: 387-417.

Furui 2011 = Ryosuke Furui. "Indian Museum Copper Plate Inscription of Dharmapala, Year 26: Tentative Reading and Study." South Asian Studies 27/2: 145-156.

Gadre 1934 = A.S. Gadre. "Five Vala Copper-Plate Grants." Journal of the University of Bombay 3: 74-91.

Gonda 1954 = Jan Gonda. Aspects of Early Viṣnuism. Leiden.

Ghoshal 1929 = U.N. Ghoshal. Contributions to the History of the Hindu Revenue System. Calcutta.

Hinüber 2005 = Oskar von Hinüber. "Der bhümicchidranyāya." Zeitschrift der Deutschen Morgenländischen Gesellschaft 155: 483-495.

Hinüber 2009 = Oskar von Hinüber. "Verwischte Spuren: Der Gebrauch buddhistischer Texte nach dem Zeugnis von Literatur, Inschriften und Dokumenten." Ed. Wolfgang Reinhard. Sakrale Texte: Hermeneutik und Lebenspraxis in den Schriftkulturen. München: 153-173, 325-334.

Hinüber 2013 = Oskar von Hinüber. "Behind the Scenes: The Struggle of Political Groups for Influence as Reflected in Inscriptions." Indo-Iranian Journal 56: 365-379. Hultzsch 1892 = Eugen Hultzsch. "A Valabhī Grant of Dhruvasena III. Dated Samvat 334." Epigraphia Indica 1: 85-92.

Jackson 1898 = A.M.T. Jackson. "Two New Valabhī Copper-Plates." Journal of the Bombay Branch of the Royal Asiatic Society 20: 1-10.

Kielhorn 1885 = Franz Kielhorn. "A Copper-Plate Grant of Siladitya I. of Valabhi." Indian Antiquary 14: 327-330.

Kielhorn 1898 = Franz Kielhorn. "Pādamūla. Pādamūlika." Indian Antiquary 27: 252. Kielhorn 1898/99 = Franz Kielhorn. "A List of the Inscriptions of Northern India from about A.D. 40o." Epigraphia Indica 5: Appendix.

Kramer 2019 = Jowita Kramer. "Sthiramati." Ed. Jonathan Silk et al. Brill's Encyclopedia of Buddhism. Vol. 2: Lives. Leiden and Boston: 456-457.

Lévi 1937 = Sylvain Lévi. "Les donations religieuses des rois de Valabhī." Mémorial Sylvain Lévi. Paris: 218-234. 
Matchett 2003 = Freda Matchett. "The Purānas." Ed. Gavin Flood. The Blackwell Companion to Hinduism. Oxford: 128-143.

Mirashi $1955=$ V.V. Mirashi. Inscriptions of the Kalachuri-Chedi Era (Corpus Inscriptionum Indicarum, vol. 4), Part 1. Ootacamund.

Monier-Williams 1899 = Monier Monier-Williams. Sanskrit-English Dictionary. Oxford. Njammasch 1971 = Marlene Njammasch. "Akhayanīvī-Schenkungen an Klöster und Tempel im Dekhan unter den Sātavāhanas.” Acta Orientalia Hungarica 24.2: 203-215. Njammasch 1985 = Marlene Njammasch. "Bemerkungen zur Herkunft und Bedeutung des Begriffs udranga (anhand nordindischer Inschriften des 5. bis 7. Jh.).” Altorientalische Forschungen 12.1: 119-128.

Njammasch 2001 = Marlene Njammasch. Bauern, Buddhisten und Brahmanen: Das frühe Mittelalter in Gujarat. Berlin.

Olivelle 2011 = Patrick Olivelle. "War and Peace: Semantics of samdhi and vigraha in the Arthaśāstra." Studia Orientalia 110: 131-139.

Pargiter 1912 = F.E. Pargiter. "Verses Relating to Gifts of Land in Indian Land Grants." Journal of the Royal Asiatic Society 1912: 248-254.

Parikh and Shelat 1988/89 = P.C. Parikh and Bharati Shelat. "Maitraka rājā Dhruvasena 2 jānum eka aprasiddha dānaśāsana Valabhī samvata 313." Sāmīpya 1: 77-84.

Salomon 2018 = Richard Salomon. "What Happened to Buddhism in India?" Journal of the International Association of Buddhist Studies 41: 1-25.

Sanderson 2009 = Alexis Sanderson. "The Śaiva Age:The Rise and Dominance of Śaivism during the Early Medieval Period." Ed. Shingo Einoo. Genesis and Development of Tantrism. Tokyo: $41-350$.

Sanderson 2015 = Alexis Sanderson. "Tolerance, Exclusivity, Inclusivity, and Persecution in Indian Religion During the Early Mediaeval Period." Ed. John Makinson. Honoris Causa: Essays in Honour of Aveek Sarkar. Allen Lane: 155-224.

Schmiedchen 1993 = Annette Schmiedchen. "Formulas Determining the Purposes of Donations to Buddhist Monasteries in West and East India from the $5^{\text {th to the }}$ 9th Cent. A.D." Ed. A.J. Gail and G.J.R. Mevissen. South Asian Archaeology 1991. Proceedings of the Eleventh International Conference of the Association of South Asian Archaeologists in Western Europe (Berlin 1-5 July 1991). Stuttgart: 585-593.

Schmiedchen 2010/11 = Annette Schmiedchen. "Religious Patronage and Political Power: The Ambivalent Character of Royal Donations in Sanskrit Epigraphy." Journal of Ancient Indian History 27: 154-166.

Schmiedchen 2016a = Annette Schmiedchen. "Religiöses Verdienst und weltliche Ambitionen: Indien.” Ed. Michael Borgolte. Enzyklopädie des Stiftungswesens in mittelalterlichen Gesellschaften. Vol. 2: Das soziale System Stiftung. Berlin: 72-85.

Schmiedchen $2016 \mathrm{~b}=$ Annette Schmiedchen. "Stiftungsvermögen und -erträge: Indien." Ed. Michael Borgolte. Enzyklopädie des Stiftungswesens in mittelalterlichen Gesellschaften. Vol. 2: Das soziale System Stiftung. Berlin: 336-354. 
Schmiedchen 2016c = Annette Schmiedchen. "Stifter: Indien." Ed. Michael Borgolte. Enzyklopädie des Stiftungswesens in mittelalterlichen Gesellschaften. Vol. 2: Das soziale System Stiftung. Berlin: 420-438.

Schmiedchen 2o16d = Annette Schmiedchen. "Stiftungsbegünstigte: Indien." Ed. Michael Borgolte. Enzyklopädie des Stiftungswesens in mittelalterlichen Gesellschaften. Vol. 2: Das soziale System Stiftung. Berlin: 497-516.

Schmiedchen 2018a = Annette Schmiedchen. "Kings, Authors, and Messengers: The Composition of the Maitraka Copper Plate Charters." Ed. Bharati Shelat and Thomas Parmar. New Horizons in Indology: Prof. Dr. H.G. Shastri Commemoration Volume. Ahmedabad: $35^{-41}$.

Schmiedchen 2018b = Annette Schmiedchen. "Imperial Rulers and Regional Elites in Early Medieval Central India (8th to 13th Centuries)." Ed. Wolfram Drews. Die Interaktion von Herrschern und Eliten in imperialen Ordnungen des Mittelalters. Berlin: 147-169.

Schmiedchen 2019 = Annette Schmiedchen. "Medieval Endowment Cultures in Western India: Buddhist and Muslim Encounters - Some Preliminary Observations." Ed. Blain Auer and Ingo Strauch. Encountering Buddhism and Islam in Premodern Central and South Asia. Berlin: 203-218.

Schopen 1994 = Gregory Schopen. "Ritual Rights and Bones of Contention. More on Monastic Funerals and Relics in the Mūlasarvāstivāda-vinaya." Journal of Indian Philosophy 22: 31-8o.

Schopen 1996 = Gregory Schopen. "The Lay Ownership of Monasteries and the Role of the Monk in Mūlasarvāstivādin Monasticism.” Journal of the International Association of Buddhist Studies 19.1: 81-126.

Shastri 1989 = H.G. Shastri. A Historical and Cultural Study of the Inscriptions of Gujarat from the Earliest Times to the End of the Caulukya Period (circa13oo A.D.). Ahmedabad. Shastri $2000=$ H.G. Shastri. Gujarat under the Maitrakas of Valabhi. Baroda.

Shastri and Dholakia 1969/70 = H.G. Shastri and P.K. Dholakia. "Valabhīnā Maitraka rājā Dhruvasena 1-lānum dānapatra." Svādhyāya 7.2: 235-239.

Shastri and Dholakia 1970/71 = H.G. Shastri and P.K. Dholakia. "Śīlāditya 1-lānum Āmbaḷāsa dānapatra." Svādhyāya 8.1: 178-184.

Silk 2009 = Jonathan A. Silk. "Remarks on the Käśyapaparivarta Commentary". Ed. Martin Straube et al. Pāsādikadānaṃ: Festschrift für Bhikkhu Pāsādika. Marburg: 381-397.

Sircar 1965 = Dinesh Chandra Sircar. Indian Epigraphy. New Delhi.

Sircar 1966 = Dinesh Chandra Sircar. Indian Epigraphical Glossary. New Delhi.

Srinivasan 1969/70 = P.R. Srinivasan. "Two Fragmentary Charters of Maitraka Dharasena IV." Epigraphia Indica 38: 219-224.

Sukthankar 1919/2O = V.S. Sukthankar. "Bhavnagar Plates of Dhruvasena I: [Valabhi-] Samvat 210." Epigraphia Indica 15: 255-258. 
Tournier 2020 = Vincent Tournier. "Buddhist Lineages along the Southern Routes: On Two nikāyas Active at Kanaganahalli under the Sātavāhanas.” Ed. V. Tournier, V. Eltschinger, and M. Sernesi. Archaeologies of the Written: Indian, Tibetan, and Buddhist Studies in Honour of Cristina Scherrer-Schaub, Naples: 859-912.

Verardi 2011 = Giovanni Verardi. Hardships and Downfall of Buddhism in India. New Delhi.

Virji 1952 = Krishnakumari J. Virji. Ancient History of Saurashtra (Being a Study of the Maitrakas of Valabhi. v то VIII Centuries A.D.). Bombay.

Visvanathan 2018 = Meera Visvanathan. "Ușavadāta's Akhayanivi: The Eternal Endowment in the Early Historic Deccan." Journal of the International Association of Buddhist Studies 41: 509-535. 
Appendix: $\quad$ Yodhāvaka Grant of Maitraka Dharasena IV, [Valabhī] year 326, Māgha ba. 5

Date:

Edition:

year 326 [of the Valabhī era], month Māgha, dark half, $5^{\text {th }}$ tithi $=$ Friday, 24th December 644 CE (if regular and pürṇimānta) ${ }^{58}$ Bhandarkar 1872: 45-46; facsimile not published, although announced in Indian Antiquary 1 (Bhandarkar 1872) no previous edition; only translation of the grant portion in

Documentation: ARIE 1963/64: p. 45, A 25 [“Museum No. B B 22 (58)"]; ARIE 1964/65: list of photographs, p. 217, no. 5134 [described as "plate facing IA 1, p. 64"]

Provenance: $\quad$ original find-spot apparently unknown; according to Bhandarkar 1872, sent to the editor of Indian Antiquary 1 (James Burgess) from Bhavnagar 59

Depository: Chhatrapati Shivaji Maharaj Vastu Sangrahalaya (csmvs), Mumbai (museum accession no. 58)

Condition: $\quad$ only the second plate of a charter of originally two plates preserved; moderate state of preservation; right-hand edge as well as some portion around the left hole broken off

Format: height of the preserved plate: $26.5 \mathrm{~cm}$; width: $32 \mathrm{~cm}$; engraved on one side only; two binding holes at the top; neither rings nor seal preserved

Language / Script: Sanskrit / Late Western Brāhmī

Summary: grant of the village of Yodhāvaka in favour of the Mahāyānikavihāra in Yodhāvaka; the only known Maitraka charter which is explicitly in favour of a Mahāyāna monastery

References: $\quad$ Kielhorn 1898/99: no. 482; Bhandarkar 1927/28-1935/36: no. 1348; Shastri 2000: 419, no. 67B; Njammasch 2001: 366, no. 73 .

Photographs: photograph of the original received from the Prince of Wales Museum (now csmvs), Mumbai, in March 1993; digital photograph received from the csmvs in October 2011

$5^{8}$ This is the earliest attested date for Dharasena IV.

59 The find-spot is not known, but the inscription records a grant in the medieval district of Hastavapra, present-day Hathab in the Bhavnagar Taluk and District, $25 \mathrm{~km}$ south-east of Bhavnagar and some $6 \mathrm{o} \mathrm{km}$ south-east of Valabhipur. 


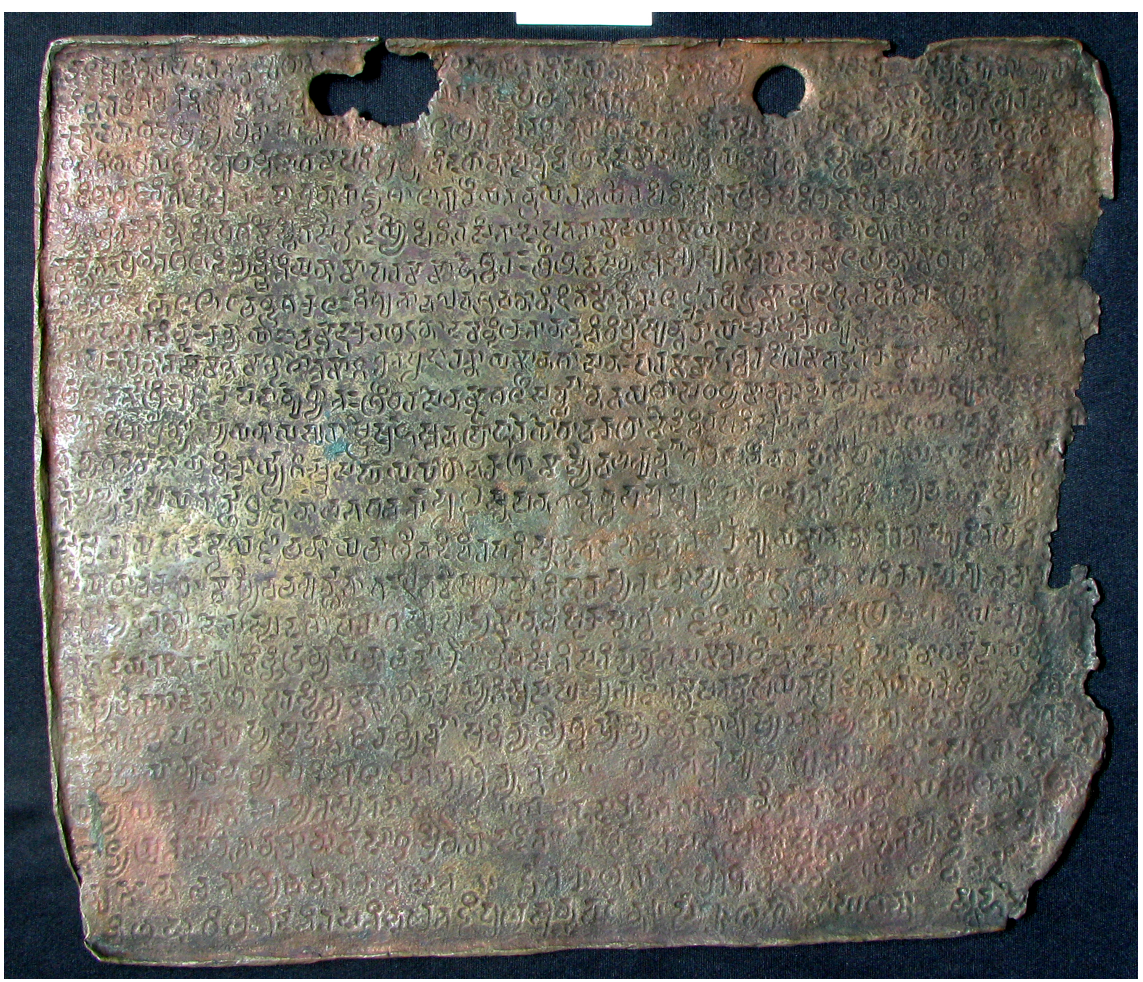

Photograph: Courtesy of Chhatrapati Shivaji Maharaj Vastu Sangrahalaya, Mumbai.

\section{Edition $^{60}$}

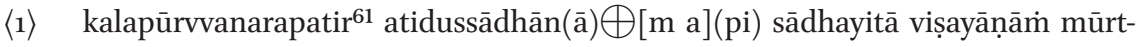
timān (iva) puĐ(ru)ṣakāra(ḥ) parivrorddhaguṇānurā(ga)-

6o The text has been read from the original as well as from the photographs. For the transliteration rules followed here, see Balogh and Griffiths 2019. The option of hyphenation in compound words is not used in this edition. These are the editorial conventions followed: $\langle 1\rangle$ for line numbers at the beginning of the line; (1) for stanza numbers; $\oplus$ for space due to the positon of the binding hole; $(\mathrm{abc})$ for text not clearly readable due to corrosion; [abc] for confidently restored text in lacunae where portions of the plate are broken off; $\{a b c\}$ for superfluous text deleted by the editor; $; a b c$ ! for scribal errors; $\langle a b c\rangle$ for supplied text, either omitted by the scribe or emended by the editor for scribal errors.

61 This is the beginning of the description of Dhruvasena II Bālāditya, the father of Dharasena IV, current ruler and issuer of this charter. The description must have started on the lost first plate. 
$\langle 2\rangle \quad$ niribh! $b\rangle$ bhara $\{c\}$ cittavrttibhir mma(nu)r iva sva $\bigoplus$ [yam abhyu]papannah prakṛtibhir adhigatakalākalā $\bigoplus p a(h)$ kāntimān nirvrótihetur akala $\langle\dot{\mathrm{n}}\rangle \mathrm{ka}(\mathrm{h})$

〈3〉 kumudanāthạ̣ prājyapratāpasthagitad(i)[gantarā]lapradhvajn!〈mìsitadhvāntarāśị satatoditas sa(vitā) prakṛtibhyah param pratyayam artthava(nta)m a(ti)-

〈4〉 bahutithaprayojanānudhandham āgamaparipūr(ṇ)ṇa(m) vidadhānas sandhivigrahasamāsaniścaya(n)ipuṇaḥ sthāne nurūpam ādeśam dada(d guṇavṛ)-

$\langle 5\rangle$ ddhivi(dh)ānajanitasamskārạ̣ sādhūnām rājyaśālāturīyatan(t)rayor ubhayor api niṣṇātah prakrșțavikramo pi karuṇāmronduhrodayah śrutavā(n a)-

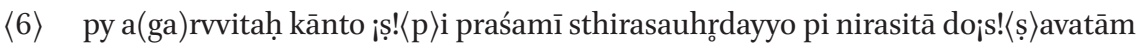
udayaipr!/s>amayasamupajanitajanānu(rāga)parip(i)hitabhu[vanasa]-

〈7〉 martthita\{h\}prathitabālādityadvitīyanāmā paramamāheśvaraḥ śrīdhruvasenas tasya sutas tatpādakamalapraṇāmadharaṇi[kaṣaṇajanita]-

〈8〉 kiṇalām(cha)nalalāțacandraśakalaḥ śiśubhāva Eva śravaṇanihitamauktikālañkāravibhramāmalaśrutaviśejs!〈ṣ)ạ̣ pradāna[salilakṣāli]-

〈9〉 tāgrahastāravindạ̣ kanyāyā Iva mrodukaragrahạ̣ād amandīkṛtānandavi-

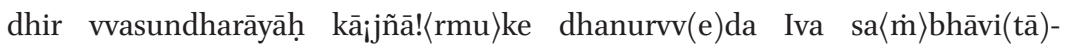
[śeșalakșaka]-

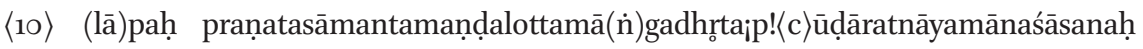

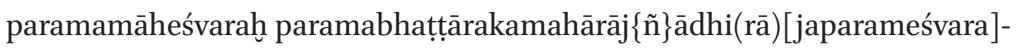

〈11〉 cakravarttiśrīAjjakapādānudhyātaḥ śrīdharasenah kuśalī sarvvān eva yathāsam(b)adhyamānakān samanudarśayaty astu vas samividitam ya[thā]

〈12〉 mātāpitroh punyāpyāyanāya surāșțreșu hịe! (a)stavaprāhāre yodhāvakagrāme divirapatiskandabhațakāritamahāyānikavihāra(ca)tu[rdi]-

〈13〉 śābhyāgatamahāyānikāryyabhikṣusamghāya yodhāvakagrāmasyaiva caturịbh!〈b〉bhāgatraya(m) cìvarapiṇ̣̣apātaśayanāsanaglānapra[tyaya]-

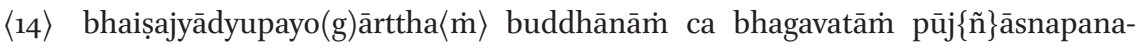
gandhadhūpapuip!/ṣ)padīpatailādyarttham vihārasya ca khaṇḍasphuṭi[taprati]-

$\langle 15\rangle$ samiskār(ā)ya pādamūlajī(v)anāya cātrai(v)a divirapatiskandabhațakhānita-

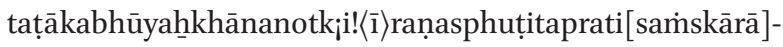

$\langle 16\rangle$ ya yodhāvakagrāmasyaiva caturthabhāgạ̣ Evam eṣa grāmo vihārasya

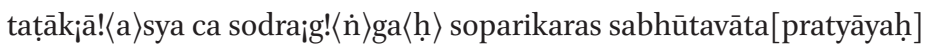

〈17〉 (sa)dhānyahiraṇyādeyas sadaśāparādhas sotpadyamānaviṣțikas sar(vv)arājakīyānām ahastaprakṣepaṇīyah pūrvvaprat(t)a[deva]-

$\langle 18\rangle$ (bra)hmadeyarahitạ̣ bhūmicchidranyāyenāca\{r\}ndrārkkārṇṇavakṣitisaritparvvatasamakālīnjāạ! $\langle a\rangle\langle U\rangle$ dakātisarggeṇa dharmmadāyo ni[șṛțo ya]-

$\langle 19\rangle$ to syocitayā devāgrāhārasthityā mahāyānikāryyabhikṣusamighasya bhu(m)jatah̄ krșatah karșayatah pradiśato vā na kaiścid vyāsedhe varttita[vyam ā]-

〈2o〉 (gāmi)bhadranrọatibhir apy asmadvañśajair anyair vvā Anityāny aiśvaryyāṇy asthiram mānuṣyam sāmānyam ca bhūmidānaphalam avaga(cchadbhi)[r aya]-

$\langle 21\rangle \quad(\mathrm{m}$ a)smaddāyo numantavya $\langle$ ḥ $\rangle$ paripālayitavyaś cety uktam ca \| 
(1) bahubhir vvasudhā bhuktā rājabhị̣ sagarādibhị̣ ya[sya] $\langle 22\rangle$ yasya yadā bhūmih tasya tasya tadā phala(M) $\|^{62}$

(2) yān(ī)ha dāridr(y)abhayān na(re)ndrair ddhanāni dharmmāyatanīkṛtāni ni[rbhukta] $\langle 23\rangle$ mālyapratimāni tāni ko nāma sādhuh punar ādadīta $\|^{63}$

(3) șaștị(m) varṣasahasrāṇi svargge tișțhati bhūmidạ̣ Ācche[ttā cā] $\langle 24\rangle$ numantā (c)a tāny eva narake vaseT $\|{ }^{64}$ dūtako tra rājaputradhruvasena(ḥ) || likhitam idam [sandhi]-

$\langle 25\rangle$ vigrahādhikrtadivirapativatrabhațtiputraskandabhațena || sam 300206 māgha ba 5 svaha(sto) [mama]

\section{Translation $^{65}$}

$\langle 1-7\rangle[\ldots]$ Śrī-Dhruvasena [II], ${ }^{66}$ highly devoted to Siva; who [...] all the former kings by [his] good deeds;

who, like an incarnation of heroism, was a conqueror even of [those] districts which are difficult to conquer;

who, like Manu himself, was petitioned by subjects whose sentiments were full of devotion because of [his] high virtues;

who, [like] the moon, mastered the arts in [their] totality (/ attained all digits), caused delight, was bright [and] faultless (/ spotless);

who, [like] a constantly rising sun, wiped out the dense darkness in the quarters [of the sky], which were covered by [his] great splendour;

who was versed in both the theories, [1] that of kingship as well as [2] that of Saalāturīya (= Pānini), ${ }^{67}$ because [(1) in politics] he inspired in [his] subjects the highest confidence, which was related to material comfort (artha), associated with quite manifold objectives, and full of profit, as he was capable of deciding on [matters of] concord, dispute, and indifference, as he gave the correct order in the [right] place, [and] as he caused the arrangement of good [people] by the rule of promotion [according] to [their] virtues (/ as [(2) in grammar] he put a suffix after roots, significant, with

62 Anușțubh metre. Cf. Pargiter 1912: 249, no. 2; Sircar 1965: 180, no. 23.

63 Indravajrā metre. Cf. Sircar 1965: 200; also 183, no. 43 and n. 2.

64 Anușțubh metre. Cf. Sircar 1965: 194, no. 123.

65 Conventions: $\langle 1-2\rangle$ for line range; (1) for stanza numbers; [...] for lost text; [abc] for restored and supplied text as well as for words inserted for clarification; (/ abc) for a pun; (= abc) for explanations added; $(a b c)$ for Sanskrit terms added.

66 Xuanzang visited the Maitraka kingdom during Dhruvasena II's reign. He describes this region without mentioning the name of the dynasty, and reports that "Dhruvapațu", the Buddhist king of Valabhī, was "a nephew of the former King Siilāditya of the country of Mālava (i.e., Maitraka Śilāditya I - As) and the son-in law of the present King Śilāditya of the country of Kanyākubja (i.e., Harșa of Kanauj - As)"; Great Tang Dynasty Record 302 (online); 342 (printed).

67 This is a pun (śleșa) on politics and grammar. For a translation of this passage, see, for instance, Hultzsch 1892: 91. 
indicatory letters for various functions, and completed by an augment, as he was wellversed in euphonic rules, the analysis of compounds, and [their] composition, as he put the correct substitute in the place [of another word], [and] as he caused the formation of correct [words] by the performance of the lengthening of vowels (guna and vrddhi);

who, although of strong prowess, had a soft heart out of mercy;

who, although learned, was not haughty;

who, although handsome, was unagitated;

who, although constant in friendship, threw out the wicked;

[and] whose famous second name Bālāditya (= "morning sun") was appropriate, as the world had been pervaded by the devotion (/ redness) of the people, which was produced at the time of [his / the sun's] rise.

$\langle 7-11\rangle$ His son Śrī-Dharasena [Iv], the paramount sovereign, overlord of great kings, supreme ruler, world emperor, highly devoted to Siva, who had been favoured by [his] respected grandfather (śri-ajjaka); ${ }^{68}$

who [like Śiva] bears a crescent of the moon on [his] forehead, i.e., the mark of a scar [produced through rubbing] the earth, while bowing down to his (= the father's) foot-lotuses;

who, already in [his] childhood, was distinguished by sacred learning, which was as spotless as the charm of the pearl-ornaments fixed to [his] ears;

the fingers of whose hand-lotuses are [washed in the water sprinkled] at donations;

who, by imposing light taxes, has intensified the creation of pleasure for the earth as if for a girl (/ by taking [her] soft hand [= marrying her]);

who, with regard to [his] bow, is like [an incarnation of] archery, as he hits [all kinds of targets];

whose decrees resemble the crest-gems which are borne on [their] heads by the circle of [his] bowing vassals - being of good health, notifies truly all [the officers] as they are concerned:

$\langle 11-18\rangle$ Be it known to you that [I] have bestowed as religious gift (dharmadāya), with a libation of water, in order to augment the religious merit of [my] parents, upon the noble Mahāyāna order of monks coming from the four directions to the Mahāyāna monastery erected by Divirapati Skandabhața in the Yodhāvaka village in the Hastavapra

68 For the meaning of ajjaka (from Sanskrit äryaka), see Fleet 1888: 186-188, n. 1. The epithet śri-ajjaka-pādānudhyāta is attested for Dharasena IV in his earliest inscriptions; it seems to refer to a specific relationship of the (new) king to his grandfather, i.e., Kharagraha I. Shastri (1989: 54) interpreted this phrase as referring to the maternal grandfather, whom he believed to have been Harșa of Kanauj. For doubts regarding this assumption, see Virji 1952: 78-79. 
district ( $\bar{a} h \bar{a} r a)$ in Surāșțra, three of the four parts of the very same Yodhāvaka village ${ }^{69}$ for the use of robes, alms-food, beds and seats, medicine to cure the sick, etc., and for fragrance, incense, flowers, lamps, oil, etc. for the cult and [ceremonial] bathing of the eminent Buddha[s], and for repairing [those parts] of the monastery [which are] split and cracked, and for the sustenance of the servants ( pādamūla), ${ }^{70}$ and the fourth part of the very same Yodhāvaka village for the further digging and excavating as well as repairing of cracked [parts] ${ }^{71}$ of the tank dug by Divirapati Skandabhața at the very same place - thus, this village for the monastery and for the tank, with principal tax (udranga), ${ }^{72}$ with additional taxes, with the [income] grown and blown, ${ }^{73}$ with the levies in corn and gold, with [the right to punish] the ten offences, with forced labour as it arises, not to be touched with the hand by all royal officers, with the exclusion of grants to [gods and] Brahmins given earlier, according to the maxim of barren land, ${ }^{74}$ to last as long as the moon, the sun, the ocean, the earth, rivers and mountains [exist]. $\langle 18-21\rangle$ Therefore, no impairment should be caused by anyone against this noble Mahāyāna order of monks, which is, according to the proper condition of a rent-free holding in favour of a deity (devāgrāhāra), enjoying [the village], cultivating [it], having [it] cultivated, or assigning [it to others for cultivation]. ${ }^{75}$ [Future] pious kings, whether born in our dynasty [or in] another, should approve of and protect [this] our donation, bearing in mind that rulership is perishable, that human existence is

69 This means that the very same village where the monastery itself had been erected was donated.

70 This is an amendment to the standard formula. For pādamüla, see Kielhorn 1898: 252; Schmiedchen 1993: 590-591. This formula appears in Maitraka endowments for Buddhist monasteries as well as for "Hindu" temples.

71 This formula seems to be rather improvised, perhaps due to the fact that a tank did not belong to the standard items mentioned in such contexts. The term bhüyah-khānana, "further digging", appears to be irregular. The expected form would be ${ }^{\circ}$ khanana, but the long $\bar{a}$ is very clear and distinct. The author might have had in mind a causative form (e.g., khānayana), like in khānita in the first part of the same compound. The word utk[ī]rana does not seem to be attested in dictionaries, but may be regarded as a kind of synonym for khanana, as ut-kirati can, inter alia, mean "to dig up, excavate"; cf. Monier Williams 1899: 176. I would like to thank Dániel Balogh for a discussion about this passage.

72 The widely used, but problematic term udranga defines the fiscal privileges of a grant; cf. Ghoshal 1929: 276, 423; Altekar 1934: 213-215; Mirashi 1955: 21, n. 6; Sircar 1966: 349; Njammasch 1985; Hinüber 2004: 313 .

73 For the formula sa-bhūta-vāta-pratyāya, see Bühler 1875a: 106. Bühler (1876a: 151) has also translated it as "together with its green and dry produce". Furthermore, Schmiedchen 2014: 144 .

74 For the interpretation of the problematic phrase bhümi-cchidra-nyāyena, see Hinüber 2005.

75 This is one of the long and comprehensive stipulations largely inspired by Brahmanical endowments. For a discussion of the potential implications of the wording of this stipulation, see above. 
uncertain, and that the reward of land grants is a common one. ${ }^{76}$ And it has been said $^{77}$ :

$\langle 21-22\rangle$ By many kings, beginning with Sagara, the earth has been enjoyed. Whosoever, at any time, possesses the land, to him belongs, at that same time, the fruit. (1)

$\langle 22-23\rangle$ Those properties which were here, out of fear of poverty, made into religious donations by kings, are similar to garlands already used [as offerings to gods]. Which good man, indeed, takes them back? (2)

$\langle 23-24\rangle$ For sixty thousand years, the giver of land rejoices in heaven. He who confiscates or approves of [the confiscation of a grant] shall live for the same [number of years] in hell. (3)

$\langle 24-25\rangle$ The messenger is prince (räjaputra) Dhruvasena in this matter. ${ }^{78}$ Written was this [charter] by Skandabhața, son of chief secretary (divirapati) Vatrabhațti, ${ }^{79}$ superintendent for [concord and] dispute. The year 326, [the month] Māgha, the dark [fortnight, the lunar day] 5. [This is] my signature.

76 Although instead of the term punya, "religious merit", the term phala, "fruit/reward" has been used in the compound bhümi-dāna-phala, "reward of land grants", this is one of the common phrases regarding the sharing of religious merit. For a discussion of the possible implications of the potential sharing of religious merit, see above.

77 Following the common practice in copper-plate charters, the Maitraka endowment records also quote several verses on the merit of granting land and on the punishment for confiscating it, which were very popular all over India, in the concluding portions of the title-deeds, or as Pargiter (1912: 248) put it more than one hundred years ago: "It was a common practice in making grants of land in ancient India for the donor to emphasize the gift and endeavour to secure its permanence by inserting in the deed of grant one or more verses which had been laid down as law regarding gifts of land. Such verses either affirmed the beneficent nature of such gifts of land, or proclaimed the merit and blessings which accrue to those who make such gifts and those who scrupulously respect them, or denounced the iniquity of those who deprived grantees of the land given, and declared the punishment which awaits such evil-doers." These are the three most popular stanzas used in Maitraka copper-plate charters.

78 The first messenger (dütaka) of Dharasena IV was prince Dhruvasena, probably his second cousin, one of the sons of his father's first cousin. Dhruvasena III (ruler no. 13 in the pedigree above) was the successor of king Dharasena IV.

79 Whereas this description makes it clear that Skandabhata II was the composer of the charter, it cannot be ruled out that the founder of the monastery had been Skandabhața I. However, I regard it to be more likely that the vihāra had been established by Skandabhața II and that the endowment had been made shortly after the foundation. 


\section{Final remark}

The title sandhivigrahädhikrta was common for the authors of Maitraka copper-plate charters. Hinüber (2009: 166 and [332,] n. 53) has translated the more complete title sandhivigrahädhikarañädhikrta, as "Vorsteher der Abteilung für (innere und äußere) Eintracht und Streit”. See for this title also Einicke 20og: 446-447; Schmiedchen 2014:189-19o. For sandhi-vigraha, see Olivelle 2011: 131139. So far, the sandhivigraha office has often been (mis)understood in a very modern way as "foreign office". Altekar (1931/32: 139), for instance, has made the following remark in this context: "The genealogy had naturally to refer to the exploits of the ancestors of the donor, material for which was expected to be preserved in the archives of the foreign office, and its head was, therefore, expected to draft the charter containing the names and exploits of the donor and his ancestors." 